\title{
Life-Sustaining Procedures, Palliative Care, and Cost Trends in Dying COPD Patients in U.S. Hospitals: 2005 2014
}

\author{
Sun Jung Kim, Ph.D., Jay Shen, Ph.D.*, Eunjeong Ko, Ph.D. ${ }^{\dagger}$, Pearl Kim, Ph.Dc.*, \\ Yong-Jae Lee, M.D. ${ }^{\ddagger}$, Jae Hoon Lee, M.D. ${ }^{\S}$, Xibei Liu, M.D. ". , Johnson Ukken, B.S. ${ }^{\mu}$, \\ Mutsumi Kioka, M.D.** and Ji Won Yoo, M.D.**
}

Department of Health Administration and Management, Soonchunhyang University, Asan, Korea, *Department of Health Care Administration and Policy, University of Nevada Las Vegas, Las Vegas, NV, ${ }^{\dagger}$ School of Social Work, San Diego State University, San Diego, CA, USA, ${ }^{\dagger}$ Department of Family Medicine, Yonsei University College of Medicine, Seoul, Korea, ${ }^{\S}$ Department of Family Medicine, University of Nevada Las Vegas School of Medicine, Las Vegas, NV, "Department of Medicine, University of Arizona College of Medicine, Tucson, AZ, "University of Nevada Reno School of Medicine, Reno, NV, **Department of Internal Medicine, University of Nevada Las Vegas School of Medicine, Las Vegas, NV, USA

Purpose: Little is known regarding the extent to which dying patients with chronic obstructive pulmonary disease (COPD) receive life-sustaining procedures and palliative care in U.S. hospitals. We examine hospital cost trends and the impact of palliative care utilization on the use of life-sustaining procedures in this population. Methods: Retrospective nationwide cohort analysis was performed using National Inpatient Sample (NIS) data from 2005 and 2014. We examined the receipt of both palliative care and intensive medical procedures, defined as systemic procedures, pulmonary procedures, or surgeries using the International Classification of Diseases, 9th revision (ICD-9-CM). Results: We used compound annual growth rates (CAGR) to determine temporal trends and multilevel multivariate regressions to identify factors associated with hospital cost. Among 77,394,755 hospitalizations, 79,314 patients were examined. The CAGR of hospital cost was $5.83 \%$ ( $\mathrm{P}<0.001)$. The CAGRs of systemic procedures and palliative care were $5.98 \%$ and $19.89 \%$ respectively (each $\mathrm{P}<0.001$ ). Systemic procedures, pulmonary procedures, and surgeries were associated with increased hospital cost by $59.04 \%, 72.00 \%$, $55.26 \%$, respectively (each $\mathrm{P}<0.001$ ). Palliative care was associated with decreased hospital cost by $28.71 \%$ ( $\mathrm{P}<0.001)$. Condusion: The volume of systemic procedures is the biggest driver of cost increase although there is a cost-saving effect from greater palliative care utilization.

Key Words: Chronic obstructive pulmonary disease, Costs and cost analysis, Health policy, Palliative care, Interrupted time series analysis
Received November 24, 2017

Revised February 11, 2018

Accepted February 20, 2018

\begin{abstract}
Correspondence to
JiWon Yoo

Department of Internal Medicine, University of Nevada Las Vegas School of Medicine, 1701 W. Charleston Blvd \#230, Las Vegas, NV 89102, USA

Tel: +1-702-671-2345

Fax: +1-702-671-2376

E-mail: ji.yoo@unlv.edu

Jay Shen, Pearl Kim, Ji Won Yoo received financial support from the Patient-Centered Outcomes Research Institute and Sun Jung Kim was supported by the Soonchunhyang University Research Fund. Funding source did not play any role for study design, data analysis and manuscript preparation.
\end{abstract}

\section{INTRODUCTION}

As life expectancy increases in U.S, healthcare spending is highly concentrated among the highest spenders (1). The top $5 \%$ of spenders account for almost half of all healthcare spending, with most costs resulting from hospital care in the last year of life (2). It is unclear whether more intensive and expensive care at the end-of-life (EOL) can be linked to be better outcomes (3-5). As acuity scores and ventilator utilization increase across U.S. intensive care units (ICUs) over the past 5 years (6), there have been growing concerns about quality of life (QOL), particularly for patients with chronic lung disease (7). COPD is currently the third leading cause of death in the U.S (8). Patients with end-stage COPD have This is an Open Access article distributed under the terms of the Creative Commons Attribution Non-Commercial License (http://creativecommons.org/licenses/by-nc/4.0/) which permits unrestricted non-commercial use, distribution, and reproduction in any medium, provided the original work is properly cited.

Copyright ( 2018 by Korean Society for Hospice and Palliative Care 
comparable or higher symptom burdens (i.e., shortness of breath, fatigue, pain, depression, and anxiety) (6,9-11) and poor QOL $(11,12)$ compared to patients with any other advanced chronic illness.

Palliative care is well-recognized as an optimal comprehensive approach for critically ill patients, particularly during EOL (12-14). It has been shown that a hospital-based palliative care service leads to positive patient satisfaction, fewer hospital admissions and in-hospital deaths, less invasive EOL treatments, or fewer hospital expenditures, all of which in turn promote quality of life (13-19). The physical and psychological needs of COPD patients during EOL are equivalent or exceed those experienced by patients with other chronic illnesses (8,20-22). Nevertheless, palliative care for COPD patients has received relatively little attention (23-26). When compared with patients with cancer or other severe chronic diseases, end-stage COPD patients were less likely to be referred for a palliative consultation (16). COPD patients are more likely than patients with other chronic illnesses to receive a disproportionate amount of life-sustaining treatment (LST) including intensive procedures $(8,27)$ and ICU admissions (28).

Previous studies of patients with chronic illnesses $(8,28,29)$ provide valuable information regarding site of death, intensive care admissions, and use of LSTs. There has also been an increase in the use of palliative care programs for major diagnoses in U.S. hospitals (30). Rush et al. (16) noted palliative care utilization increased 4.5-fold between 2006 and 2012 in patients with end-stage COPD and home oxygen use. Nevertheless, little is known about the temporal changes of LSTs and palliative care services, and their effects on hospital cost, particularly among dying patients with COPD. Using a nationally representative database, we examine 10-year trends of LSTs in U.S hospitals such as systemic procedures, local procedures, surgeries and palliative care utilization in dying COPD patients.

\section{METHODS}

\section{Data source}

This study is a serial, cross-sectional data analysis. We met all of the requirements without explicitly stating the Strength- ening the Reporting of Observational Studies in Epidemiology (STROBE) guidelines (31). We used the NIS database which is a product of the Healthcare Cost and Utilization Project (HCUP) and is sponsored by the Agency for Healthcare Research and Quality (AHRQ) (32). The NIS database is the largest publicly available all-payer inpatient database in the U.S. and includes data from over 7 million hospital inpatient stays each year. The NIS represents a $20 \%$ sample of all nonfederal, short-term hospitals from 44 states in the U.S. and is therefore capable of estimating the delivery of approximately $96 \%$ of all hospital inpatient stays in 2014 (33). The NIS represents the care delivered at more than 4,000 hospitals. It also contains random samples of hospitalizations classified by HCUP member hospitals and stratified by location, teaching status, and bed-size as indicated on the American Hospital Association Annual Survey of Hospitals (34). Each year, NIS data reflects new hospitalizations from these HCUP member hospitals. The analysis of the NIS uses completely de-identified data with no risk of confidentiality loss. We completed a data user agreement with the AHRQ prior to using the NIS database. Since the data were from a completely de-identified dataset, an institutional review board approval was waived from University of Nevada Las Vegas.

\section{Patient cohort selection}

The 2005 2014 NIS datasets were used for analysis. We applied survey weights and adjustment to provide annual national population estimates. Our population of interest was patients ages 18 or older who died during their hospitalization. Patients were identified as having COPD as principal diagnosis, LSTs (systemic procedures, local procedures, surgeries), and palliative care by using ICD-9-CM codes for COPD (Table 1). Quality control procedures performed by the HCUP have demonstrated reliability and accuracy, specifically when data contains the principal diagnosis (34). The patient cohort selection process is depicted in Figure 1. Patient-level characteristics from the database included age, gender, race, number of comorbidities, severity of illness using all-patient refined diagnosis-related group (APR-DRG), primary payer (Medicare, private insurance, Medicaid, others), and the zip code-based annual median household income. Hospital characteristics included information regarding location, teaching status, and bed-size. 
Table 1. ICD-9-CM Codes used for Main Disease, Systemic Procedures, Local Procedure, Surgeries, and Palliative Care.

\begin{tabular}{|c|c|c|}
\hline & Diagnostic categories & ICD-9-CM codes \\
\hline $\begin{array}{l}\text { Principal } \\
\text { diagnosis }\end{array}$ & COPD & $\begin{array}{l}\text { 491.0, 491.1, 491.20, 491.21, 491.22, 491.8, 491.9, 493.2, 492.0, 492.8, 494.0, 494.1, } \\
\text { 496, 506.4 }\end{array}$ \\
\hline \multirow{8}{*}{$\begin{array}{l}\text { Systemic } \\
\text { procedures }\end{array}$} & Intubation & $96.01,96.02,96.03,96.04,96.05$ \\
\hline & Mechanical ventilation & $96.70,96.71,96.72$ \\
\hline & Non-invasive ventilation & 93.90 \\
\hline & $\begin{array}{l}\text { Infusion of vasopressor or intravascular } \\
\text { pressure measurement }\end{array}$ & $0017,0067,0068,0069$ \\
\hline & $\begin{array}{l}\text { Enteral or parenteral infusion of } \\
\text { concentrated nutrition }\end{array}$ & $99.60,99.15$ \\
\hline & Cardiopulmonary resuscitation & 99.60 \\
\hline & Blood transfusion & $99.00,99.01,99.02,99.04,99.05,99.06,99.07,99.08,99.09$ \\
\hline & Hemodialysis & 39.95, V45.11, V56.0 \\
\hline $\begin{array}{l}\text { Local } \\
\text { procedures }\end{array}$ & Thoracentesis or bronchoscopies & $\begin{array}{l}\text { 32.01, 32.24, 32.28, 33.21, 33.22, 33.23, 33.24, 33.26, 33.27, 33.71, 33.72, 33.72, 33.73, } \\
\text { 33.78, 34.91, 34.92 }\end{array}$ \\
\hline \multirow[t]{4}{*}{ Surgeries } & Larynx, pharynx & $\begin{array}{l}29.00,29.11,29.12,29.19,29.39,29.40,29.51,29.54,29.59,29.91,29.99,30.09,30.10 \\
\quad 30.21,30.22,30.29,30.30,30.40,31.00,31.48,31.61 ., 31.62,31.71,31.98\end{array}$ \\
\hline & Trachea & $\begin{array}{l}\text { 31.10, 31.21, 31.29, 31.30, 31.45, 31.49, 31.50, 31.71, 31.72, 31.73, 31.74, 31.75, 31.79, } \\
\text { 31.92, 31.94, 31.99 }\end{array}$ \\
\hline & Bronchus, lung & 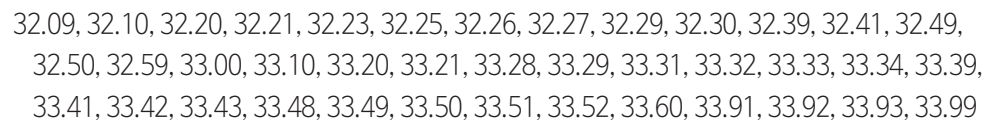 \\
\hline & Chest wall, pleura & $\begin{array}{c}34.01,34.02,34.03,34.04,34.05,34.06,34.09,34.10,34.20,34.21,34.22,34.23,34.24 \\
34.26,34.28,34.29,34.30,34.40,34.51,34.52,34.59,34.60,34.71,34.72,34.73\end{array}$ \\
\hline Palliative care & & V66.7 \\
\hline
\end{tabular}

ICD-9-CM: International Classification of Diseases, 9th revision, Clinical Modification, COPD: chronic obstructive pulmonary disease.

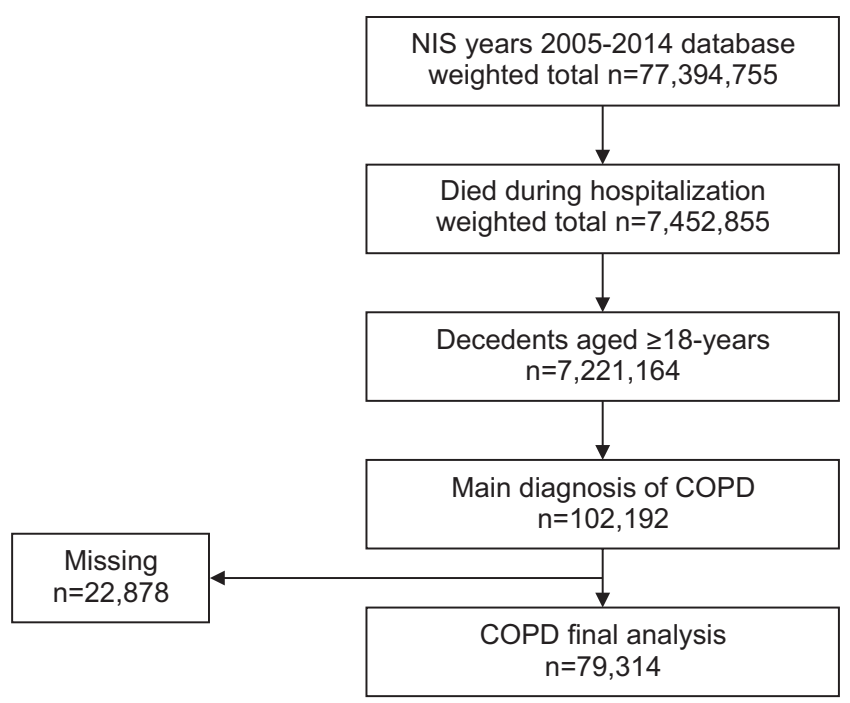

Figure 1. Patient cohort selection process.

COPD: chronic obstructive pulmonary disease, NIS: national inpatient sample.

\section{Variables of interest}

The main outcomes were the proportion of patients with LSTs (systemic procedures, local procedures, surgeries), and palliative care by year. Systemic procedures were defined as eight groups: 1) intubation, 2) mechanical ventilation (MV), 3) non-invasive ventilation (NIV), 4) vasopressor use, intravascular pressure monitoring, 5) enteral, parenteral infusion of concentrated nutrition, 6) cardiopulmonary resuscitation (CPR), 7) blood transfusion, or 8) hemodialysis. Local procedures were those relevant to COPD patients including thoracentesis or any type of bronchoscopy. Surgeries were relevant to COPD patients including those involving larynx, pharynx, trachea, bronchus, lung, chest wall, or pleura. We calculated the total cost of each hospitalization provided by HCUP by applying hospital-specific and group-average all-payer inpatient cost-to-charge ratios from the Centers for Medicare and Medicaid Services (CMS) to the reported hospital charges. Hospital costs were then adjusted for the annual inflation rate using CMS estimates and were expressed as annual means with 95\% confidence intervals (CIs) in 2014 U.S. dollars (35). 


\section{Statistical analysis}

First, the CAGR was used to quantify temporal trends of LSTs and palliative care and its statistical significance was tested by Rao-Scott correction for $\chi^{2}$ tests for categorical variables. CAGR supposes that year A is $\mathrm{x}$ and year B is $\mathrm{y}$, CAGR $=(y / x)^{\{1 /(B-A)\}-1}$ and has been widely used for health care valuation $(36,37)$. Pearson $x^{2}$ test for temporal trends in clustered binary data (yes/no) was limited for testing homogeneity in a population with a skewed distribution (38). Hierarchical modeling analysis was applied to adjust for multi-levels of $\mathrm{pa}^{-}$ tient and hospitals as suggested by the HCUP when analyzing the NIS dataset (39). Because the distribution of hospital cost was skewed, log-transformation was applied to a regression model. Multilevel and multivariate regression analysis of hospital cost was performed to determine the effects of patients, hospital factors, LSTs (systemic procedures, local procedures, surgeries), and palliative care on hospital cost. Based on the results from regression analyses, further exploratory analyses were conducted examining the statistical difference of illness severity 1) between systematic procedures and palliative care, and 2) between private insurance and Medicaid. Also, the statistical difference of LSTs and palliative care between private insurance and Medicaid was tested using the Rao-Scott correction of $x^{2}$ test. To evaluate the impact of missing data, we compared baseline characteristics. We multiply imputed missing hospital cost using regression analysis models. There were no statistical differences among baseline characteristics between analyzed and missing data. The model was determined to be stable and the assumption of randomly missing data was found to be reasonable using the observed data. All analyses were performed using SAS statistical software version 9.4 (SAS Institute Inc., Cary, NC). All reported $\mathrm{P}$-values were 2-tailed and $\mathrm{P}-$ value $<0.05$ was considered statistically significant.

\section{RESULTS}

\section{Descriptive statistics}

From 2005 to 2014, the NIS database contained 77,394,755 hospital inpatient stays; 7,221,164 terminal hospitalizations with age $\geq 18$ years; 102,192 patients with main diagnosis of
Table 2. Descriptive Analysis of Patient Cohort $(N=79,314)$.

\begin{tabular}{|c|c|}
\hline Variables & $\%$ (n) or mean (standard deviation) \\
\hline Age (yr) & $75.02(18.08)$ \\
\hline Number of comorbidities & $3.14(4.03)$ \\
\hline Male & $48.39 \%(38,387)$ \\
\hline \multicolumn{2}{|l|}{ Race } \\
\hline White & $85.23 \%(67,607)$ \\
\hline Black & $6.69 \%(5,310)$ \\
\hline Hispanic & $4.39 \%(3,483)$ \\
\hline Other & $3.69 \%(2,914)$ \\
\hline \multicolumn{2}{|l|}{ Severity of illness } \\
\hline APR-DRG 1 least severe & $4.83 \%(3,817)$ \\
\hline APR-DRG 2 & $14.07 \%(11,166)$ \\
\hline APR-DRG 3 & $34.27 \%(27,188)$ \\
\hline APR-DRG 4 most severe & $46.83 \%(37,143)$ \\
\hline Lung cancer & $6.11 \%(4,848)$ \\
\hline \multicolumn{2}{|l|}{ Primary payer } \\
\hline Medicare & $76.33 \%(60,538)$ \\
\hline Private insurance & $13.36 \%(10,594)$ \\
\hline Medicaid & $4.34 \%(3,449)$ \\
\hline Other & $5.97 \%(4,733)$ \\
\hline \multicolumn{2}{|c|}{ Zip code annual household income } \\
\hline $0 \sim 25^{\text {th }}$ percentile & $30.92 \%(24,526)$ \\
\hline $26^{\text {th }} \sim 50^{\text {th }}$ percentile & $27.17 \%(21,554)$ \\
\hline $51^{\text {st }} \sim 75^{\text {th }}$ percentile & $22.06 \%(17,501)$ \\
\hline $76^{\text {th }} \sim 100^{\text {th }}$ percentile & $19.85 \%(15,733)$ \\
\hline \multicolumn{2}{|c|}{ Hospital location and teaching status } \\
\hline Urban teaching & $32.41 \%(25,709)$ \\
\hline Urban nonteaching & $47.45 \%(37,635)$ \\
\hline Rural & $20.14 \%(15,970)$ \\
\hline \multicolumn{2}{|l|}{ Hospital bed size } \\
\hline Small & $18.50 \%(14,676)$ \\
\hline Medium & $26.47 \%(20,995)$ \\
\hline Large & $55.03 \%(43,643)$ \\
\hline Systemic procedures & $52.05 \%(41,288)$ \\
\hline Local procedures & $7.87 \%(6,247)$ \\
\hline Surgeries & $3.68 \%(2,921)$ \\
\hline Palliative care & $29.95 \%(23,756)$ \\
\hline
\end{tabular}

COPD; final analysis included 79,314 patients as shown in Figure 1. Table 2 presents a descriptive analysis of patient and hospital characteristics. More than half of patients received systemic procedures $(52.05 \%)$, while less than one in ten patients received local procedures $(7.87 \%)$ or surgeries $(3.68 \%)$; $29.95 \%$ received palliative care.

\section{Temporal trends statistics}

Figure 2 presents the CAGRs of LSTs and palliative care. The CAGRs of systemic procedures, local procedures, surgeries, 


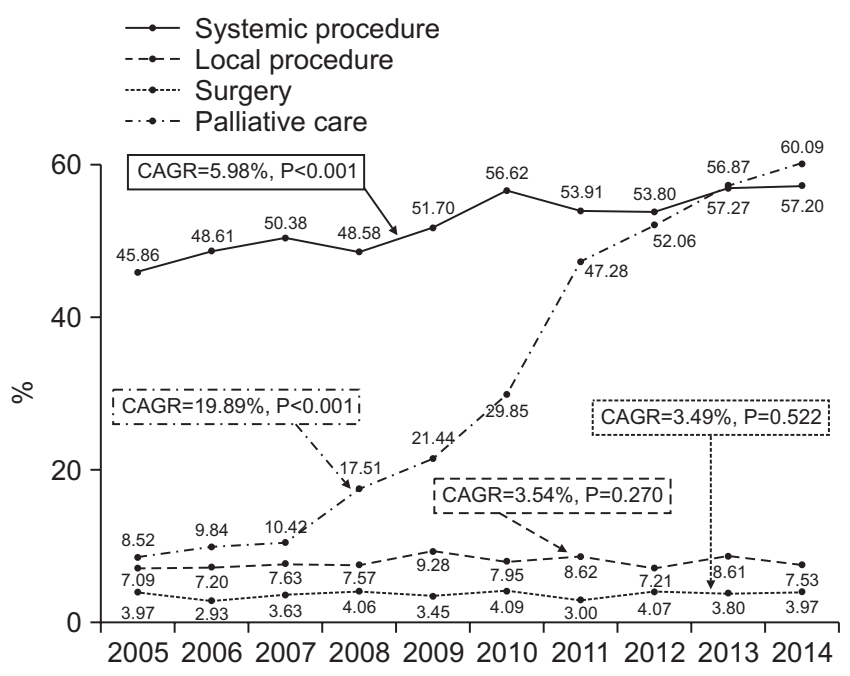

Figure 2. Compound annual growth rates of life-sustaining procedures and palliative care.

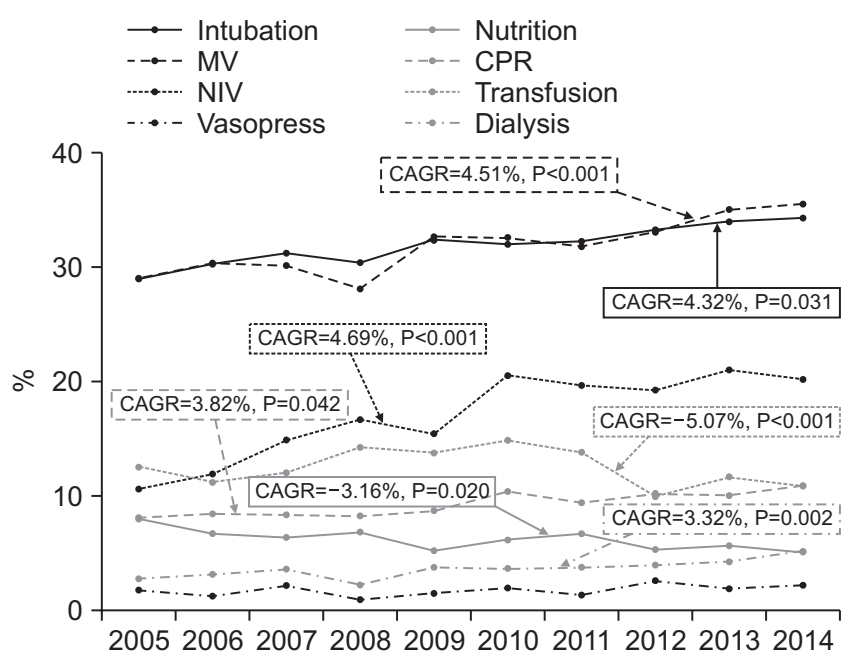

Figure 3. Compound annual growth rates (CAGR) of each systemic procedure items.

MV: mechanical ventilation, NIV: non-invasive ventilation, CPR: cardiopulmonary resuscitation.

and palliative care were $5.98 \%, 3.54 \%, 3.49 \%$, and $19.89 \%$. Systemic procedures and palliative care increased over time (both $\mathrm{P}<0.001$ ), but the proportions of local procedures and surgeries were unchanged over time.

Figure 3 presents the CAGRs of each kind of systemic procedure. The CAGRs of intubation, MV, NMV, CPR, and hemodialysis were $4.32 \%, 4.51 \%, 4.69 \%, 3.82 \%, 3.32 \%$, and these items increased over time (all $\mathrm{P}<0.05)$. However, the CAGRs of enteral/parenteral infusion of concentrated nutrition and blood transfusion were $-3.16 \%$ and $-5.07 \%$ and these items decreased over time $(\mathrm{P}=0.020 ; \mathrm{P}<0.001$, respectively). Vaso-

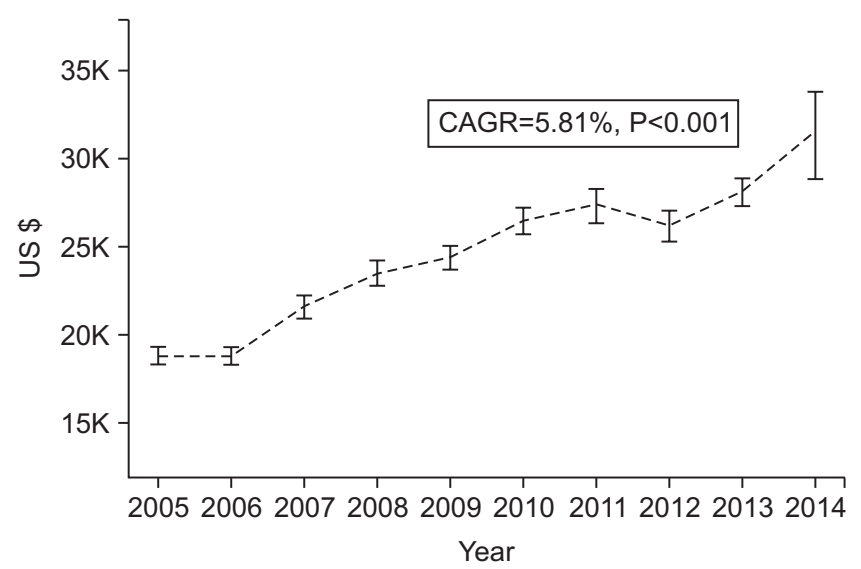

Figure 4. Annual mean and 95\% confidence intervals of hospital cost and compound annual growth rate of hospital cost.

CAGR: compound annual growth rates.

pressor use/intravascular monitoring was unchanged.

Figure 4 presents annual mean and 95\% CI of hospital cost. The hospital cost increased over time $(\mathrm{P}<0.001)$ and the CAGR was $5.81 \%$.

\section{Log-transformed multivariate regression analysis of hospital cost}

Table 3 presents log-transformed multi-level multivariate regression analysis of hospital cost. Each year increased hospital cost by $0.0581(\mathrm{P}<0.001)$ that can be interpreted as a CAGR of $5.81 \%$. Black patients (estimate $=0.069 ; \mathrm{P}=0.029$ ) and other non-Hispanic patients (estimate $=0.072 ; \mathrm{P}=0.011$ ) were associated with increased hospital cost compared to white counterparts. Higher APR-DRG patients were associated with increased hospital cost. Compared with private insurance patients, Medicare (estimate $=0.480 ; \mathrm{P}<0.001$ ) and Medicaid (estimate $=0.461 ; \mathrm{P}<0.001$ ) patients were associated with increased hospital cost. Higher income patients were associated with increased hospital cost. A small hospital was associated with increased hospital cost (estimate $=0.064$; $\mathrm{P}=0.003$ ). Systemic procedures (estimate $=0.590 ; \mathrm{P}<0.001$ ), local procedures (estimate $=0.720 ; \mathrm{P}<0.001$ ), or surgeries (estimate $=0.552 ; \mathrm{P}<0.001)$ were associated with increased hospital cost. Palliative care was associated with decreased hospital cost (estimate $=-0.287$; $\mathrm{P}<0.001$ ).

\section{Exploratory analyses}

Figures 5 and 6 present statistically significant differences $(\mathrm{P}<$ 
Table 3. Log-transformed Multivariate Regression Analysis of Hospital Cost.

\begin{tabular}{|c|c|c|}
\hline Variables & Estimate & $P$ \\
\hline Year & 0.058 & $<0.001$ \\
\hline Age & 0.011 & $<0.001$ \\
\hline Male & 0.009 & 0.532 \\
\hline \multicolumn{3}{|l|}{ Race: white, referent } \\
\hline Black & 0.069 & 0.029 \\
\hline Hispanic & 0.064 & 0.092 \\
\hline Others & 0.072 & 0.011 \\
\hline \multicolumn{3}{|c|}{ Severity of illness: APR-DRG 1, referent } \\
\hline APR-DRG 2 & 0.301 & $<0.001$ \\
\hline APR-DRG 3 & 0.748 & $<0.001$ \\
\hline APR-DRG 4 & 1.149 & $<0.001$ \\
\hline Lung cancer & 0.048 & 0.106 \\
\hline \multicolumn{3}{|c|}{ Primary payer: private insurance, referent } \\
\hline Medicare & 0.480 & $<0.001$ \\
\hline Medicaid & 0.461 & $<0.001$ \\
\hline Others & 0.024 & 0.116 \\
\hline \multicolumn{3}{|c|}{ Zip code annual household income: $0 \sim 25^{\text {th }}$ percentile, referent } \\
\hline $26^{\text {th }} \sim 50^{\text {th }}$ percentile & 0.016 & 0.420 \\
\hline $51^{\text {st }} \sim 75^{\text {th }}$ percentile & 0.087 & $<0.001$ \\
\hline $76^{\text {th }} \sim 100^{\text {th }}$ percentile & 0.170 & $<0.001$ \\
\hline \multicolumn{3}{|c|}{ Hospital location and teaching status: urban teaching, referent } \\
\hline Urban nonteaching & 0.006 & 0.297 \\
\hline Rural & -0.007 & 0.243 \\
\hline \multicolumn{3}{|c|}{ Hospital bed size: large, referent } \\
\hline Small & 0.064 & 0.003 \\
\hline Medium & -0.006 & 0.690 \\
\hline Systemic procedures & 0.590 & $<0.001$ \\
\hline Local procedures & 0.720 & $<0.001$ \\
\hline Surgeries & 0.552 & $<0.001$ \\
\hline Palliative care & -0.287 & $<0.001$ \\
\hline
\end{tabular}

0.001) of APR-DRG illness severity between systemic procedures and palliative care (Figure 5) and between private insurance and Medicaid (Figure 6). Higher APR-DRG patients were more likely to receive systemic procedures rather than palliative care; Medicaid patients were more likely to have higher APR-DRG compared to private insurance patients. Figure 7 presents health service utilization differences between private insurance and Medicaid patients. Medicaid patients were more likely to receive LSTs (all systemic procedures, local procedures, and surgeries; all $\mathrm{P}<0.001$ ) and were less likely to receive palliative care compared to their private insurance counterparts $(\mathrm{P}<0.001)$.

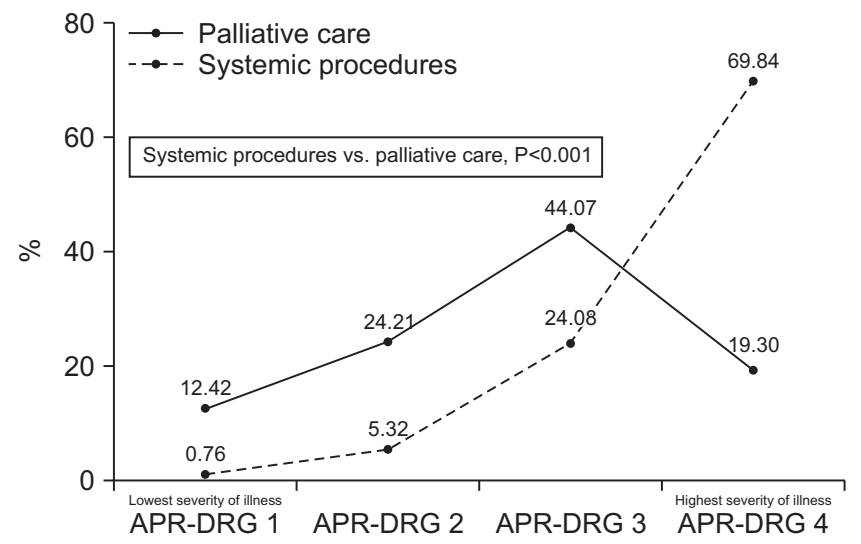

Figure 5. Severity of illness (APR-DRG) comparison between systemic procedure and palliative care.

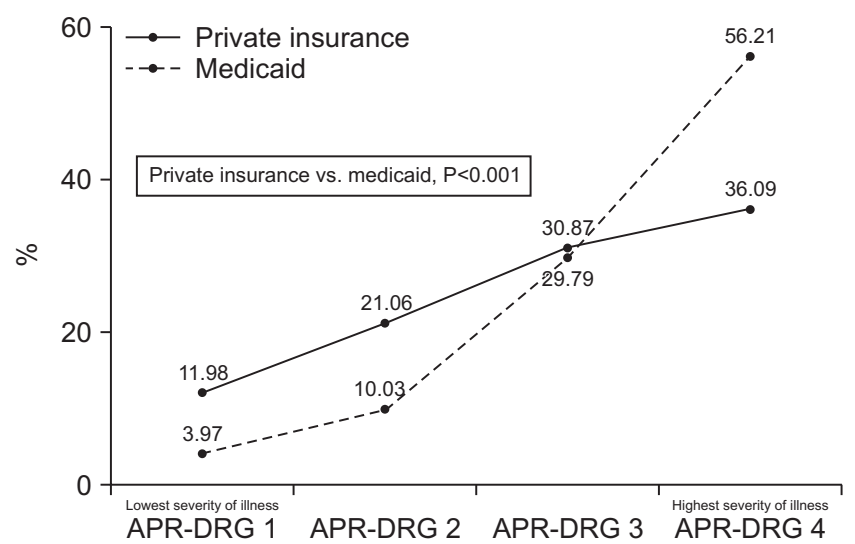

Figure 6. Severity of illness (APR-DRG) comparison between private insurance and medicaid patients.

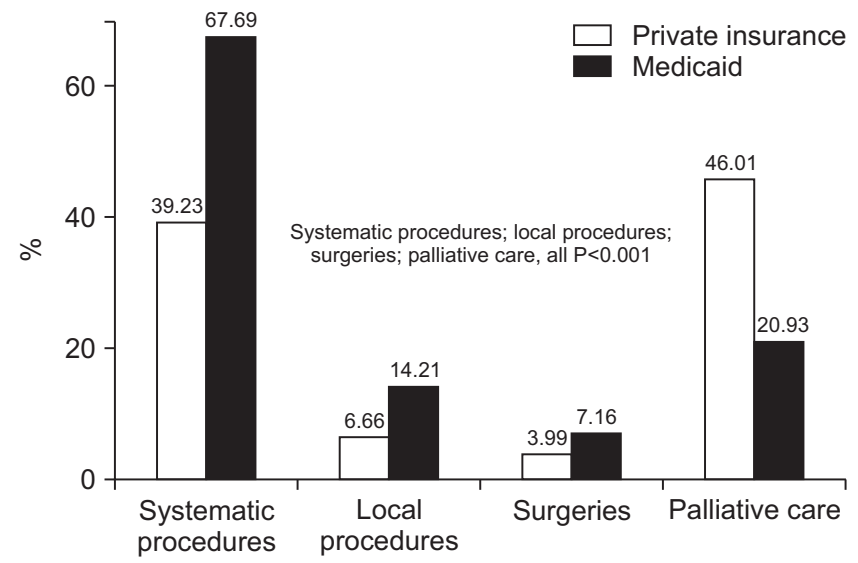

Figure 7. Health care utilization differences between private insurance and medicaid patients.

\section{DISCUSSION}

To the best of our knowledge, the current study reports the first ten-year national temporal trends of LSTs, palliative care, 
and their effects on hospital cost in dying COPD patients in U.S. hospitals. The major temporal trends were increased systemic procedures and palliative care, without change in local procedures and surgeries. Teno et al. (29) found that ICU care increased from 2000 to 2009, with $29.2 \%$ of decedents in 2009 experiencing an ICU care in the last months of life. In our analysis, respiratory tract supporting systemic procedures such as intubation, MV, or NIV, were the most common procedures, which might be linked with the national increase in MV and NIV ICU utilization reported by Lilly et al. (7) and other nationally representative findings from Tschirhart et al. (5). Perhaps a late referral for hospital-based palliative consultation or hospice referral resulted in initiation of LST until the goal of care is firmly established by the patient or by healthcare proxy. This dilemma is particularly challenging for noncancer patients. Unlike typical cancer patients whose prognosis is predictable, the disease trajectories for chronic advanced non-cancer disease, such as COPD, are heterogeneous which makes it difficult to accurately assess prognosis $(23,27,34,40)$ and introduce palliative care appropriately. In contrast, other systemic procedures such as blood transfusion and nutrition decreased over time. These findings are consistent with recent reports identifying that restrictive red cell transfusion is not inferior to liberal transfusion except for heart disease (41) and that percutaneous gastrostomy tube feeding might not improve survival or aspiration pneumonia risks when compared to conservative approaches such as nasogastric tube feeding (42).

Compared to the previous reports on patients with advanced COPD by Rush et al. (16) (1.7\%), the magnitude of palliative care utilization in our study indicates it is much more common (29.95\%). Current hospital-based palliative care programs alone may not be sufficient to affect critical illness care utilization such as length of stay and reciprocal hospice care enrollment among critically ill patients requiring hospital inpatient care (43). In addition, Yaqoob et al. (44) reported that national hospice care in patients dying with COPD has been increasing from 2.2\% in 2006 to $9.3 \%$ in 2015, but, is still under-utilized. Palliative care's impact on healthcare utilization such as ICU care and medical procedures can be largely and more directly linked with cancer patients as compared to non-cancer patients $(15,18)$. Data collection limited to dying patients and more recent years (2013 and 2014) might explain the increase more palliative care utilization.

The more interesting finding is the increased pattern of palliative care utilization with a "level and slope change" (45). A pattern of exponential increase started from 2008 and persisted until 2011. There is a plateau from 2012 until 2014. The efforts of healthcare professional societies such as the American College of Chest Physicians (ACCP) to promote EOL communication and advance care planning (ACP) was brought to fruition in dying COPD patients $(46,47)$. The momentum of another "level and slope change" in palliative care is expected around 2016 when the CMS began to allow healthcare providers to bill for ACP discussion time using two new Current Procedural Terminology (CPT) codes, 99497 and 99498 from January 2016 (48).

Hospital cost increases over time in our analysis. We apply higher inflation rate using the CMS' measurement of hospital care compared to the inflation rate using the Consumer Price Index (CPI) for medical care available from the U.S. Bureau of Labor Statistics (49). We observe the cost-saving effect of palliative care as seen in previous cost analysis studies $(15,18,50)$, but we add the findings of a cost-increase effect of LSTs. The magnitude of cost-increases from LSTs (systematic procedures 59.0\%; local procedures $72.0 \%$; surgeries $55.2 \%$ ) exceeded the cost-saving effect of palliative care $(-28.7 \%)$; therefore, annual hospital cost increased by $5.81 \%$ in our study.

We find health insurance effects on different health outcomes. Medicaid patients are sicker than private insurance patients. There is a disparity of LSTs and palliative care utilization between private insurance and Medicaid patients. Medicaid patients receive more LSTs and less palliative care compared to private insurance patients. We speculate that Medicaid COPD patients not only receive less preventive care before hospital admission but also discuss ACP less frequently compared to private insurance patients.

We acknowledge several limitations. We relied on ICD-9CM codes that may have limited accuracy in capturing procedures and palliative care due to incorrect or missing data. Second, we could not capture stage or pharmacologic treatment of COPD before and during hospital care. Third, the NIS dataset could link the purpose of local procedures or surgeries, palliative vs. life-sustaining, suggesting that these procedures or surgeries might have been performed for both or either pal- 
liative or life-sustaining purposes. Given the largest dataset and 10-year study period, we believe that secular trends in our study are likely generalizable to most U.S. dying patients with COPD.

Among dying adults with COPD in the U.S. hospitals from 2005 to 2014, the increasing volume of systemic procedures is the biggest driver of increased cost although we observe a cost-saving effect from increased utilization of palliative care.

\section{요약}

목적: 미국 병원에서 만성폐색성폐질환으로 사망하는 환자의 연명 치료 및 완화의료에 대한 연구는 부족한 현실이다. 이 연구에서는 병 원의 의료비 추세 및 완화의료 이용 및 연명치료 이용과의 관련성을 파악하고자 하였다.

방법: 이 연구는 2005 2014년 미국 입원환자 샘플(National Inpatient Sample, NIS)을 후향적 코호트 디자인으로 전환하였으며, ICD-9-CM (International Classification of Diseases, 9th revision)
코드를 활용하여 완화의료 및 집중치료(전신지지치료, 호흡기치료, 호흡기 수술)를 받은 환자를 구분하였다.

결과: 연평균성장률(Compound Annual Growth Rates, CAGR)을 활용하여 병원 의료비의 시계열변화를 확인하였으며, 다수준 다변량 회귀분석을 통해 병원의 의료비에 영향을 미치는 요소를 파악하였 다. 전체 $77,394,755$ 입원 건 중 79,314 명의 환자가 최종 분석에 사 용되었다. 병원 의료비는 연평균성장률이 $5.83 \%$ ( $\mathrm{P}<0.001)$ 였으며, 전신지지치료와 완화의료의 연평균성장률은 각각 $5.98 \%$ 와 $19.89 \%$ 였다(모두, $\mathrm{P}<0.001$ ). 전신지지치료, 호흡기 치료, 호흡기 수술은 각 각 $59.04 \%, 72.00 \%, 55.26 \%$ 의 병원 의료비 상승에 영향을(모두, P $<0.001)$ 주었던 반면 완화의료는 $28.71 \%$ 의 병원 의료비 감소에 영 향을 주었다 $(\mathrm{P}<0.001)$.

결론: 미국에서 만성폐색성폐질환으로 사망하는 환자 중 전신지지 치료는 병원 의료비 상승의 주된 원인인 반면 완화의료 이용은 비용 절감에 영향이 있는 것으로 파악되었다.

중심단어: 만성폐색성폐질환, 의료비 및 의료비 분석, 보건정책, 완 화의료, 단절적 시계열 분석

\section{REFERENCES}

1. Kaiser Family Foundation. Health status of the Medicare population. A primer on Medicare [Internet]. Menlo Park, CA: Kaiser Family Foundation; 2015 [cited 2017 Oct 17]. Available from: http://files.kff.org/attachment/report-a-primer-on-medicare-key-facts-about-themedicare-program-and-the-people-it-covers.

2. NIHCM Foundation. Health care's big spenders: the characteristics behind the curve [Internet]. Washington, DC: National Institute for Health Care Management Foundation; 2017 [cited 2017 Oct 17]. Available from: http://www.NIHCM.org.

3. Barnato AE, Chang CH, Farrell MH, Lave JR, Roberts MS, Angus DC. Is survival better at hospitals with higher "end-of-life" treatment intensity? Med Care 2010;48:125-32.

4. Ornstein KA, Aldridge MD, Garrido MM, Gorges R, Bollens-Lund E, Siu AL, et al. The use of life-sustaining procedures in the last month is associated with more depressive symptoms in surviving spouses. J Pain Symptom Manage 2017;53:178-87.

5. Tschirhart EC, Du Q, Kelley AS. Factors influencing the use of intensive procedures at the end of life. J Am Geriatr Soc 2014;62:2088-94.

6. Claessens MT, Lynn J, Zhong Z, Desbiens NA, Phillips RS, Wu AW, et al. Dying with lung cancer or chronic obstructive pulmonary disease: insights from SUPPORT. Study to Understand Prognoses and Preferences for Outcomes and Risks of Treatments. J Am Geriatr Soc 2000;48(5 Suppl):S146-53.

7. Lilly CM, Swami S, LiuX, Riker RR, Badawi O. Five year trends of critical care practice and outcomes. Chest 2017;152:723-35.

8. Kochanek KD, Murphy SL, Xu J, Tejada-Vera B. Deaths: final data for 2014. Natl Vital Stat Rep 2016;65:1-122.

9. Weingaertner V, Scheve C, Gerdes V, Schwarz-Eywill M, Prenzel R, Bausewein C, et al. Breathlessness, functional status, distress, and palliative care needs over time in patients with advanced chronic obstructive pulmonary disease or lung cancer: a cohort study. J Pain Symptom Manage 2014;48:569-81.

10. Shin J, Park HY, Lee J. Hospice and palliative care in chronic obstructive pulmonary disease. Korean J Hosp Palliat Care 2017;20:81-92.

11. Habraken JM, ter Riet G, Gore JM, Greenstone MA, Weersink EJ, Bindels PJ, et al. Health-related quality of life in end-stage COPD and lung cancer patients. J Pain Symptom Manage 2009;37:973-81.

12. Wachterman MW, Pilver C, Smith D, Ersek M, Lipsitz SR, Keating NL. Quality of end-of-life care provided to patients with different serious illnesses. JAMA Intern Med 2016;176:1095-102.

13. Aslakson RA, Curtis JR, Nelson JE. The changing role of palliative care in the ICU. Crit Care Med 2014;42:2418-28.

14. Temel JS, Greer JA, Muzikansky A, Gallagher ER, Admane S, Jackson VA, et al. Early palliative care for patients with metastatic non-smallcell lung cancer. New Engl J Med 2010;363:733-42. 
15. May P, Garrido MM, Cassel JB, Kelley AS, Meier DE, Normand C, et al. Cost analysis of a prospective multi-site cohort study of palliative care consultation teams for adults with advanced cancer: Where do cost-savings come from? Palliat Med 2017;31:378-86.

16. Rush B, Hertz P, Bond A, McDermid RC, Celi LA. Use of palliative care in patients with end-stage COPD and receiving home oxygen: National trends and barriers to care in the United States. Chest 2017;151:41-6.

17. Brumley R, Enguidanos S, Jamison P, Seitz R, Morgenstern N, Saito S, et al. Increased satisfaction with care and lower costs: results of a randomized trial of in-home palliative care. J Am Geriatr Soc 2007;55:993-1000.

18. May P, Garrido MM, Cassel JB, Kelley AS, Meier DE, Normand C, et al. Palliative care teams' cost-saving effect is larger for cancer patients with higher numbers of comorbidities. Health Aff (Millwood) 2016;35:44-53.

19. Liu X, Dawod Y, Wonnaparhown A, Shafi A, Doo L, Yoo JW, et al. Effects of hospital palliative care on health, length of stay, and in-hospital mortality across intensive and non-intensive-care units: A systematic review and metaanalysis. Palliat Support Care 2017;15:741-52.

20. Gore JM, Brophy CJ, Greenstone MA. How well do we care for patients with end stage chronic obstructive pulmonary disease (COPD)? A comparison of palliative care and quality of life in COPD and lung cancer. Thorax 2000;55:1000-6.

21. Bausewein C, Booth S, Gysels M, Kuhnbach R, Haberland B, Higginson IJ. Individual breathlessness trajectories do not match summary trajectories in advanced cancer and chronic obstructive pulmonary disease: results from a longitudinal study. Palliat Med 2010;24:777-86.

22. Edmonds P, Karlsen S, Khan S, Addington-Hall J. A comparison of the palliative care needs of patients dying from chronic respiratory diseases and lung cancer. Palliat Med 2001;15:287-95.

23. Curtis JR. Palliative and end-of-life care for patients with severe COPD. Eur Respir J 2008;32:796-803.

24. Vermylen JH, Szmuilowicz E, Kalhan R. Palliative care in COPD: an unmet area for quality improvement. Int J Chron Obstruct Pulmon Dis 2015;10:1543-51.

25. Schroedl CJ, Yount SE, Szmuilowicz E, Hutchison PJ, Rosenberg SR, Kalhan R. A qualitative study of unmet healthcare needs in chronic obstructive pulmonary disease. A potential role for specialist palliative care? Ann Am Thorac Soc 2014;11:1433-8.

26. Brown CE, Jecker NS, Curtis JR. Inadequate palliative care in chronic lung disease. an issue of health care inequality. Ann Am Thorac Soc 2016;13:311-6.

27. Brown CE, Engelberg RA, Nielsen EL, Curtis JR. Palliative care for patients dying in the intensive care unit with chronic lung disease compared with metastatic cancer. Ann Am Thorac Soc 2016;13:684-9.

28. Au DH, Udris EM, Fihn SD, McDonell MB, Curtis JR. Differences in health care utilization at the end of life among patients with chronic obstructive pulmonary disease and patients with lung cancer. Arch Intern Med 2006;166:326-31.

29. Teno JM, Gozalo PL, Bynum JP, Leland NE, Miller SC, Morden NE, et al. Change in end-of-life care for Medicare beneficiaries: Site of death, place of care, and health care transitions in 2000, 2005, and 2009. JAMA 2013;309:470-7.

30. Meier DE, Back AL, Berman A, Block SD, Corrigan JM, Morrison RS. A national strategy for palliative care. Health Aff (Millwood) 2017;36: 1265-73.

31. von Elm E, Altman DG, Egger M, Pocock SJ, Gøtzsche PC, Vandenbroucke JP, et al. The Strengthening the Reporting of Observational Studies in Epidemiology (STROBE) statement: guidelines for reporting observational studies. Lancet 2007;370:1453-7.

32. Agency for Healthcare Research and Quality. Healthcare Cost and Utilization Project [Internet]. Rockville, MD: Agency for Healthcare Research and Quality; 2017 [cited 2017 Oct 17]. Available from: http://www.hcup-us.ahrq.gov/db/quality.jsp.

33. Agency for Healthcare Research and Quality. Healthcare Cost and Utilization Project. 2014 Introduction to the NIS [Internet]. Rockville, MD: Agency for Healthcare Research and Quality; 2017 [cited 2017 Oct 17]. Available from: http://www.hcup-us.ahrq.gov/db/nation/nis/NIS_ Introduction_2014.jsp.

34. Barnato AE, Cohen ED, Mistovich KA, Chang CC. Hospital end-of-life treatment intensity among cancer and non-cancer cohorts. J Pain Symptom Manage 2015;49:521-9.

35. Martin AB, Hartman M, Benson J, Catlin A; National Health Expenditure Accounts Team. Nation health spending in 2014; faster growth driven by coverage expansion and prescription drug spending. Health Aff (Millwood) 2016;35:150-60.

36. Moses H 3rd, Matheson DH, Dorsey ER, George BP, Sadoff D, Yoshimura S. The anatomy of health care in the United States. JAMA 2013; 310:1947-63.

37. Cimasi RJ. Healthcare valuation. Chapter 8. Valuation approaches and methods. Hoboken, New Jersey:Wiley;2014. p. 39-44. (The series in Wiley finance series; vol. 1).

38. Rao JNK, Scott AJ. A simple method for the analysis of clustered binary data. Biometrics 1992;48:577-85.

39. Houchens R, Chu B, Steiner C. HCUP methods series. Report \#2014-04 [Internet]. Rockville, MD: Agency for Healthcare Research and Quality; 2017 [cited 2017 Oct 18]. Available from: http://www.hcup-us.ahrq.gov/reports/methods/jsp.

40. Casanova C, de Torres JP, Aguirre-Jaíme A, Pinto-Plata V, Marin JM, Cordoba E, et al. The progression of chronic obstructive pulmonary disease is heterogeneous: the experience of the BODE cohort. Am J Respir Crit Care Med 2011;184:1015-21.

41. Holst LB, Petersen MW, Hasse N, Perner A, Wetterslev J. Restrictive versus liberal transfusion strategy for red blood cell transfusion: systematic review of randomized trials with meta-analysis and trial sequential analysis. BMJ 2015;350:h1354.

42. Teno JM, Gozalo PL, Mitchell SL, Kuo S, Rhodes RL, Bynum JP, et al. Does feeding tube insertion and its timing improve survival? J Am Geriatr Soc 2012;60:1918-21. 
43. Horton JR, Morrison RS, Capezuti E, Hill J, Lee EJ, Kelley AS. Impact of inpatient palliative care on treatment intensity for patients with serious illness. J Palliat Med 2016;19:936-42.

44. Yaqoob ZJ, Al-Kindi SG, Zein JG. Trends and disparities in hospice use among patients dying of COPD in the United States. Chest 2017;151: 1183-4.

45. Lopez Bernal J, Cummins S, Gasparrini A. Interrupted time series regression for the evaluation of public health interventions: a tutorial. Int J Epidemiol 2017;46:348-55.

46. Selecky PA, Eliasson CA, Hall RI, Schneider RF, Varkey B, McCaffree DR, et al. Palliative and end-of-life care for patients with cardiopulmonary diseases: American College of Chest Physicians position statement. Chest 2005;128:3599-610.

47. Knauft E, Nielsen EL, Engelberg RA, Patrick DL, Curtis JR. Barriers and facilitators to end-of-life care communication for patients with COPD. Chest 2005;127:2188-96.

48. Center for Medicare and Medicaid Services. Final rule policies for ACP delineated in the CY 2016 PFS final rule (80 Fed. Reg. 70955 through 70959) [Internet]. Baltimore, MD: Center for Medicare and Medicaid Services; 2016 [cited 2017 Oct 17]. Available from: https://www.cms. gov/Medicare/Medicare-Fee-for-Service-Payment/PhysicianFeeSched/PFS-Federal-Regulation-Notices.html.

49. U.S. Bureau of Labor Statistics. Consumer price index, US average medical care from 2005 to 2014 [Internet]. Washington, DC: U.S. Bureau of Labor Statistics; 2017 [cited 2017 Oct 17]. Available from: http://www.bls/gov/cpi.

50. Dzingina MD, Reilly CC, Bausewein C, Jolley CJ, Moxham J, McCrone P, et al. Variations in the cost of formal and informal health care for patients with advanced chronic disease and refractory breathlessness: A cross-sectional secondary analysis. Palliat Med 2017;31:369-77. 